\title{
Dental anomalies in the primary dentition of Turkish children
}

\author{
Arife Kapdan' \\ Alper Kustarci² \\ Burak Buldur ${ }^{1}$ \\ Dilara Arslan ${ }^{2}$ \\ Alper Kapdan²
}

\section{ABSTRACT}

Objective: The aim of this study was to determine the prevalence of double teeth, hypodontia, microdontia, and hyperdontia of primary teeth in Turkish children.

Methods: The study group comprised 1149 children (554 girls, 595 boys). The children were examined in twelve local nurseries in Sivas, Turkiye. Clinical data were collected by four dentists according to Kreiborg criteria; which includes double teeth, hypodontia, microdontia, and supernumerary teeth. Statistical analysis of the data was performed using the chi-square test.

Results: Dental anomalies were found in $2.0 \%$ of children. The distribution of dental anomalies were significantly more frequent $(P=.023)$ in boys $(2.9 \%, n=17)$ than in girls $(1.1 \%, n=6)$. In relation to anomaly frequencies at different ages, no difference was found $(P=.760)$.

Conclusion: Double teeth were the most frequently (1.3\%) observed anomaly. The other anomalies followed as; $0.3 \%$ supernumerary teeth, $0.3 \%$ microdontia, $0.2 \%$ hypodontia. Identification of dental anomalies in the anterior region at an early age is of great importance for esthetic and orthodontic treatment planning. (Eur J Dent 2012;6:178-183)

Key words: Hypodontia; supernumerary teeth; fused teeth; primary dentition

\section{INTRODUCTION}

The development of the human dentition is regulated by tissue interactions and genetic networks similar to those of other ectodermal organs and involves iterative and self-organizing mechanisms

- 1 Department of Pediatric Dentistry, Faculty of Dentistry, Cumhuriyet University, Sivas, TURKIYE

2 Department of Restorative Dentistry and Endodontics, Faculty of Dentistry, Cumhuriyet University, Sivas, TURKIYE

- Corresponding author: Dr. Arife Kapdan Cumhuriyet Universitesi, Dishekimligi Fakultesi, Cucuk Dishekimligi AD. Sivas, TURKIYE Tel: +90 3462191010 int 2757

Fax: +90 3462191237

Email: arife sozendyahoo.com crucial for the serial organization of teeth and their shape and renewal. ${ }^{1-3}$ Various types of developmental aberrations are common in teeth, including abnormalities in the structure of enamel and dentine and in the shape, size, and number of teeth.

Dental anomalies involving the number of teeth include hypodontia (one or more missing teeth), oligodontia (six or more missing teeth), anodontia (complete absence of teeth), and hyperdontia (one or more extra teeth, also known as supernumeraries). Alterations in the size of teeth include microdontia (teeth smaller than normal) and macrodontia (teeth larger than normal). Both these conditions may be either generalized to all the teeth or isolat- 
ed to one or several teeth. Variations in the shape of teeth include double teeth (fusion and gemination), talon cusp, dens evaginatus, and dens invaginatus (dens in dente). ${ }^{4}$ Early diagnosis of dental anomalies, particularly in the primary dentition, should allow for more comprehensive long-term treatment planning, more favorable prognosis, and, in certain instances, less extensive interception ${ }^{5-7}$

The prevalence of dental anomalies in the primary dentition has been reported in with a number of previous studies. ${ }^{8-11}$ Esenlik et al $^{12}$ were found that the prevalence of decidious and permanent supernumerary teeth were $0.4 \%$ and $2.3 \%$. Uslu et $\mathrm{al}^{13}$ reported a $0.3 \%$ prevalence of supernumerary teeth, $0.7 \%$ prevalence of microdontia, and $21.6 \%$ prevalence of agenesis in permanent teeth. AltugAtac and Erdem ${ }^{14}$ reported that 3043 orthodontic patients had 166 (5.46\%) developmental dental anomalies. Although there has been a few study about dental anomalies in permanent teeth, ${ }^{12-14}$ the frequency of dental anomalies in primary dentition in Turkish people is not well documented in the literature. Therefore, we aimed to evaluate the frequency, distribution, differences between sexes, and characteristics of dental anomalies in the primary dentition in a referred Turkish population.

\section{MATERIALS AND METHODS}

The subjects of the study were 1149 children (554 girls and 595 boys) aged 2-5 years. The children were examined in the twelve nurseries in the city of Sivas in Turkiye. The city of Sivas has an approximate population of 300,000 , and all households have access to public water supply (fluoride level: 0.3-0.4 ppm).

\section{Clinical dental examination}

Clinical data were collected in the nurseries by four dentists. The examinations were conducted with the children sitting on ordinary chairs. First, the teeth were cleaned and dried with gauze. The clinical examination was exclusively visual, aided by a tongue depressor. Dental anomalies representing variations in tooth size, morphology, and number were recorded according to the criteria described by Kreiborg et al: ${ }^{15}$ (1) Local microdontia: single tooth smaller than normal; (2) Fusion: union in dentin and/or enamel between two or more separately developed normal teeth; (3) Gemination: incomplete division of a tooth germ; (4) Hypodontia: absence of one or only a few teeth; (5) Hyperdontia: presence of a supernumerary tooth. Because the clinical distinction between fusion and gemination is difficult, these were grouped under the term "double teeth" as suggested by Carvalho et al. ${ }^{16}$

\section{Statistical Analysis}

Statistical analysis of the data was performed using the chi-square test. To quantify the association between gender, age, and the presence of concurrent anomalies, prevalence ratios (PRs) and $95 \%$ confidence interval (CI) were calculated.

\section{RESULTS}

To allow comparison with results from other populations, results of previous studies are summarized in Table 1. Sample distribution and prevalence of dental anomalies according to gender and age are shown in Table 2. Anomalies were observed in 23 children, representing an overall prevalence of $2.0 \%$. The distribution of dental anomalies were significantly more frequent $(P=.023)$ in boys $(2.9 \%$, $\mathrm{n}=17)$ than in girls $(1.1 \%, \mathrm{n}=6)$. In relation to anomaly frequencies at different ages, no difference was found between the frequencies observed $(P=.760)$ : $2.8 \%$ at 3 years old, $1.9 \%$ at 4 years old, and $2.1 \%$ at 5 years old. At 2 years old, anomalies were not seen.

Table 3 shows the distribution of individual anomalies among children according to gender and location on the upper and/or lower arch. A total of 15 children had double teeth (1.3\%); 2 children presented hypodontia $(0.2 \%), 1$ presented unilateral hypodontia, and 1 presented bilateral hypodontia (total = 3 teeth: 3 lower central incisors); 3 children presented supernumerary teeth $(0.3 \%)$; and 3 children presented microdontia $(0.3 \%)$, with 2 presenting unilateral microdontia and 1 presenting bilateral microdontia (total = 4 teeth: 4 lower central). The low frequencies observed make it difficult to make statistical inferences from these data.

\section{DISCUSSION}

When epidemiological studies are checked out, it is understood that most of it occurs in places where there are children such as schools, nurseries etc.. In the present study, the reason of why there are small number test subjects regarding 2-aged and 3-aged groups is the deficiency of these age groups in our region. 
The prevalence of dental anomalies observed in this study $(2.0 \%)$ was greater than that reported by Menczer, ${ }^{17}$ Grahnen and Granath, ${ }^{18}$ Magnusson, ${ }^{19}$ Jones et $\mathrm{al}^{20}{ }^{20}$ Whittington and Durward, ${ }^{6}$ Plaetschke, ${ }^{21}$ Toth and Csemi, ${ }^{22}$ Carvalho et al, ${ }^{16}$ and Esenlik et al $(0,4 \%), 12$ whose results varied between $0.4 \%$ and $1.74 \%$. The frequencies reported by Clayton (7.4\%), ${ }^{23}$ Yonezu et al (7.2\%), ${ }^{7}$ Altug-Atac and Erdem (5.46\%), ${ }^{14}$ Brook (3.2\%), ${ }^{5}$ Niswander and Sujaku (2.5\%), ${ }^{24}$ Kramer et al (2.5\%), ${ }^{11}$ and Ravn $(2.1 \%),{ }^{9}$ however, were greater than the present study. These results may reflect racial characteristics, but the differences should be interpreted in accordance with the methodology used. Studies by Clayton $^{23}$ and Yonezu et al, ${ }^{7}$ which reported a high proportion of children with dental anomalies, were conducted on children who attended clinical sevices. This fact could have led to overestimation of outcomes in relation to the general population. ${ }^{11}$

In this study, boys had significantly more anomalies than girls (Table 2). This finding is confirmed by previously published work. ${ }^{7}$ In the permanent dentition, Brook ${ }^{25}$ found that males more often presented supernumerary teeth and females more frequently presented hypodontia, and these differences were statistically significant. According to findings by

Table 1. Prevalence surveys of dental anomalies in primary dentition in different countries.

\begin{tabular}{|c|c|c|c|c|c|c|}
\hline Studies & Country & Sample size & $\begin{array}{c}\text { Supernumerary } \\
\text { teeth }\end{array}$ & Hypodontia & Double teeth & Microdontia \\
\hline Plaetschke, $1938^{21}$ & Germany & 1000 & 0,2 & 0,7 & 0,5 & - \\
\hline Menczer, $1955^{17}$ & USA & 2209 & 0,2 & 0,1 & 0,1 & - \\
\hline Clayton, $1956^{23}$ & USA & 1795 & 1,8 & 4,6 & 0,8 & 0,2 \\
\hline Grahnen\& Granath, $1961^{18}$ & Sweden & 1173 & 0,3 & 0,4 & 0,5 & - \\
\hline Niswander \& Sujaku, $1963^{24}$ & Japan & 285 & - & - & 2,5 & - \\
\hline Toth \& Csemi, $1965^{22}$ & Germany & 2539 & - & - & 0,6 & - \\
\hline Ravn, $1971^{9}$ & Denmark & 4564 & 0,6 & 0,6 & 0,9 & - \\
\hline Brook, $1974^{5}$ & England & 741 & 0,8 & 0,3 & 1,6 & 0,5 \\
\hline Magnusson, $1984^{19}$ & Iceland & 572 & 0,5 & 0,5 & 0,7 & - \\
\hline Jones et al, $1993^{20}$ & USA & 493 & 0,2 & 0 & 0,4 & - \\
\hline Whittington \&Durward, $1996^{6}$ & New Zealand & 1680 & 0,2 & 0,4 & 0,8 & - \\
\hline Yonezu et al, $1997^{7}$ & Japan & 2733 & 0,1 & 2,4 & 4,1 & 0,6 \\
\hline Carvalho et al, $1998^{16}$ & Belgium & 750 & 0,8 & 0,4 & 0,6 & 0,1 \\
\hline Altug-Atac \& Erdem, $2007^{14}$ & Turkey & 3043 & - & 2,63 & 0,23 & 1,58 \\
\hline Kramer et al, $2008^{11}$ & Brazil & 1260 & 0,3 & 0,6 & 1,3 & 0,3 \\
\hline Esenlik et al,2009 ${ }^{12}$ & Turkey & 2599 & $\begin{array}{c}0,4 \\
\text { (decidiousteeth) } \\
2,3 \\
\text { (permanentteeth) }\end{array}$ & - & - & - \\
\hline Uslu et al, $2009^{13}$ & Turkey & 900 & 0,3 & 21,6 & - & 0,7 \\
\hline
\end{tabular}

Table 2. Prevalence ratio (PR) and $95 \%$ confidence intervals $(95 \% \mathrm{Cl}$ ) for associations between demographic variables and dental anomalies.

\begin{tabular}{lccc}
\hline Variable & $\mathrm{N}(\%)$ & With anomalies & $\mathrm{PR}(95 \% \mathrm{Cl})$ \\
\hline Gender & $554(48,2)$ & & \\
Female & $595(51,8)$ & $17,1)$ & \\
Male & & $17(2,9)$ & $2,89(1,123-7,23)$ \\
\hline Age & $38(3,3)$ & & - \\
2 & $109(9,5)$ & $3(2,8)$ & $1,73(0,40-4,68)$ \\
3 & $371(32,3)$ & $7(1,9)$ & $0,86(0,35-2,09)$ \\
5 & $631(54,9)$ & $13(2,1)$ & $1,15(0,50-2,61)$ \\
\hline
\end{tabular}

$N$, number of children examined; $n$, number of children with dental anomalies.

${ }^{*} \mathrm{P}<.05$ 
Brook, ${ }^{5}$ Magnusson, ${ }^{19}$ Ravn, ${ }^{9}$ Hagman, ${ }^{26}$ Jarvinen et al, ${ }^{27,28}$ McKibben and Brearley, ${ }^{29}$ and Whittington and Durward, ${ }^{6}$ Esenlik et al ${ }^{12}$ gender and anomalies were not associated. Uslu et $\mathrm{al}^{13}$ reported Statistically significant correlations were not observed between sex and dental anomalies, with the exception of microdontia and ectopic eruption, seen only in females.

In the present study, the differences were not statistically significant in distribution of dental anomalies according to age (Table 2). Similar findings for anomalies at different ages of primary dentition have been observed in previous studies. ${ }^{6}$ $9,11,19,30$

Analysis of the frequency and location of each anomaly revealed consistency with data from previous studies. The anomaly with the greatest prevalence in this study was double teeth, with a prevalence of $1.3 \%$ (Table 3), which agrees with the prevalence of $1.3-4.1 \%$ reported in other studies.5,7,11,18,19,24 The unilateral occurrence of this anomaly and its presence in the lateral incisor region coincide with the majority of previous studies. $.7,7,9,17,20,27$ The location of double teeth in the anterior area of the mouth is also in agreement with previous findings. ${ }^{18,23,29,30}$

Double teeth may adversely affect esthetics, and may lead to dental crowding and difficulty in eruption of adjacent teeth. Treatment consists of managing asymmetry, either by extirpation of the unwanted dental portion in conjunction with root canal therapy, or restoration of the exposed area. Orthodontic intervention completes the treatment plan. ${ }^{31}$
In the present study, prevalence of hypodontia was $0.2 \%$, supernumerary teeth was $0.3 \%$, and microdontia was $0.3 \%$ (Table 3 ), all less than $0.5 \%$, similar to previously published works. ${ }^{6,17-20}$ Frequencies above $0.5 \%$ have been reported by Clayton (1956: hypodontia, 4.6\%; supernumerary, $1.8 \%$ ), ${ }^{23}$ Ravn (1971: hypodontia and supernumerary, 0.6\%), ${ }^{9}$ Brook (1974: supernumerary, 0.8\%; microdontia, 0.5\%), ${ }^{5}$ Yonezu et al (1997: hypodontia, 2.4\%; microdontia, 0.6\%), ${ }^{7}$ Carvalho (1998: supernumerary, $0.8 \%),{ }^{16}$ and Plaetschke (1938: hypodontia, 0.7\%). ${ }^{21}$ Hypodontia almost exclusively affects the lateral incisors, which corresponds to Grahnen and Granath's ${ }^{18}$ report, whereas Plaetschke ${ }^{21}$ and Clayton $^{23}$ found the central incisors as frequently involved as the lateral incisors. Children with hypodontia in the primary dentition present corresponding missing permanent teeth, 6,9,20 indicating the importance of early diagnosis with regard to adequate medium and long-term treatment planning.

Treatment generally requires a multidisciplinary approach including orthodontic correction, or prosthetic replacement with a removable or fixed appliance. Age of the patient, number of missing teeth, carious teeth, and condition of supporting tissues, occlusion and interocclusal space are the important factors determining treatment planning. ${ }^{31}$

Supernumerary teeth, defined as teeth additional to those of the normal series, have been reported as most prevalent in the maxillary anterior region, the lateral incisors being most frequently involved. 9,18,26,32-34 It was striking that supernumerary teeth in the lateral incisors area were normal in form, whereas in the region of the central inci-

Table 3. Dental anomalies distribution according to gender (unit of analysis: children) and dental arch (unit of analysis: teeth).

\begin{tabular}{|c|c|c|c|c|c|c|}
\hline Unit of analysis and variables & $\mathrm{N}$ & Supernumerary & Hypodontia & Double teeth & Microdontia & Anomaly \\
\hline & & $\mathrm{n}[\%]$ & $\mathrm{n}(\%)$ & $\mathrm{n}(\%)$ & $\mathrm{n}(\%)$ & $\mathrm{n}(\%)$ \\
\hline Children: overall & 1149 & $3(0,3)$ & $2(0,2)$ & $15(1,3)$ & $3(0,3)$ & \\
\hline \multicolumn{7}{|l|}{ Gender } \\
\hline Female & 554 & $1(16,7)$ & --- & $4(66,7)$ & $1(16,7)$ & $6(100,00)$ \\
\hline Male & 595 & $2(11,8)$ & $2(11,8)$ & $11(64,7)$ & $2(11,8)$ & $17(100,00)$ \\
\hline Teeth & & 3 & 3 & 17 & 4 & 27 \\
\hline \multicolumn{7}{|l|}{ Arch } \\
\hline Lower & & $1(5,6)$ & $2(11,1)$ & $12(66,7)$ & $3(16,7)$ & $18(100,00)$ \\
\hline Upper & & $2(4,0)$ & --- & $3(60,0)$ & --- & $5(100,00)$ \\
\hline Unilateral & & $3(15,8)$ & $1(5,3)$ & $13(68,4)$ & $2(10,5)$ & $19(100,00)$ \\
\hline Bilateral & & --- & $1(25,0)$ & $2(50,0)$ & $1(25,0)$ & $4(100,00)$ \\
\hline
\end{tabular}

$N$, number of children examined; $n$, number of children or teeth with dental anomalies. ${ }^{*} P<.05$ 
sor they had the form of peg-teeth. Saarenmaa ${ }^{35}$ has drawn attention to the same condition among a Finnish population. Supernumerary canines are uncommon, though they are described in the literature..$^{36-38}$

Microdontia is an anomaly characterized by marked reduction in crown diameter. The findings of this study confirm the low prevalence suggested by other studies, between $0.1 \%$ and $0.6 \% .5,7,11,16,23 \mathrm{~A}$ diagnosis of microdontia is based on evaluation of crown size, which is a more subjective criterion and subject to error, in relation to the diagnosis of other anomalies.

The identification of dental anomalies in the anterior region at an early age is of great importance for esthetic and orthodontic treatment planning. ${ }^{16}$ Epidemiological studies have provided useful information regarding the prevalence, location, and distribution of primary tooth anomalies, contributing to the formulation of public health policies adequately informed by the specificities of each population.

\section{CONCLUSION}

Our data emphasize the importance of encouraging parents to visit the dentist with their children at an early age. It also illustrates the need for a detailed and careful clinical examination by the dentist. These aids in effective and long-term treatment planning according to a child's individual requirements.

\section{REFERENCES}

1. Jernvall J, Thesleff I. Reiterative signaling and patterning during mammalian tooth morphogenesis. Mech Dev 2000;92:19-29.

2. Kavanagh KD, Evans AR, Jernvall J. Predicting evolutionary patterns of mammalian teeth from development. Nature 2007:449:427-432.

3. Thesleff I, Nieminen P. Tooth induction. Encyclopedia of life sciences. Helsinki; Finland, 2006;132.

4. Stecker SS, Beiraghi S, Hodges JS, Peterson VS, Myers SL. Prevalence of dental anomalies in a Southeast Asian population in the Minneapolis/Saint Paul metropolitan area. Northwest Dent 2007;86:25-28.

5. Brook AH. Dental anomalies of number, form and size: their prevalence in British schoolchildren. J Int Assoc Dent Child 1974;5:37-53.

6. Whittington BR, Durward CS. Survey of anomalies in primary teeth and their correlation with the permanent dentition. N Z Dent J 1996:92:4-8.
7. Yonezu T, Hayashi Y, Sasaki J, Machida Y. Prevalence of congenital dental anomalies of the deciduous dentition in Japanese children. Bull Tokyo Dent Coll 1997;38:27-32.

8. Nik-Hussein NN, Abdul Majid Z. Dental anomalies in the primary dentition: distribution and correlation with the permanent dentition. J Clin Pediatr Dent 1996;21:15-19.

9. Ravn JJ. Aplasia, supernumerary teeth and fused teeth in the primary dentition. An epidemiologic study. Scand J Dent Res 1971;79:1-6.

10. Ooshima T, Ishida R, Mishima K, Sobue S. The prevalence of developmental anomalies of teeth and their association with tooth size in the primary and permanent dentitions of 1650 Japanese children. Int J Paediatr Dent 1996;6:87-94.

11. Kramer PF, Feldens CA, Ferreira SH, Spiguel MH, Feldens EG. Dental anomalies and associated factors in 2- to 5-yearold Brazilian children. Int J Paediatr Dent 2008;18:434-440.

12. Esenlik E, Sayın MO, Atilla AO, Ozen T, Altun C, Basak F. Supernumerary teeth in a Turkish population. Am J Orthod Dentofacial Orthop 2009;136:848-852.

13. Uslu O, Akcam MO, Evirgen S, Cebeci I. Prevalence of dental anomalies in various malocclusions. Am J Orthod Dentofacial Orthop 2009;135:328-335.

14. Altug-Atac AT and Erdem D. Prevalence and distribution of dental anomalies in orthodontic patients. Am J Orthod Dentofacial Orthop 2007;131:510-514.

15. Kreiborg S, Egemark-Erickson I, Jensen BL, Nyström M. Disturbances of occlusal development and function. In: Koch G, Modeer T, Poulsen S, Rasmussen P(eds). Pedodontics:a Clinical Approach. Copenhagen; Munksgaard, 1994; 275-92.

16. Carvalho JC, Vinker F, Declerck D. Malocclusion, dental injuries and dental anomalies in the primary dentition of Belgian children. Int J Paediatr Dent 1998;8:137-141.

17. Menczer L. Anomalies of the primary dentition. J Dent Child 1955;22:57-62.

18. Grahnen H, Granath LE. Numerical variations in primary dentition and their correlation with the permanent dentition. Odontol Revy 1961;12:348-357.

19. Magnusson TE. Hypodontia, hyperodontia, and double formation of primary teeth in Iceland. An epidemiological study. Acta Odontol Scand 1984;42: 137-139.

20. Jones ML, Mourino AP, Bowden TA. Evaluation of occlusion, trauma, and dental anomalies in African-American children of metropolitan Headstart programs. J Clin Pediatr Dent 1993;18:51-54.

21. Plaetschke J. Okklusions anomalien im Milchgebiss. Dtsch. Zahn-, Mund- u. Kieferheilk 1938;5:435-451.

22. Toth A, Csemi L. Zwillingszahne im Milchgebiss. Dtsch. Zahnarztl Z 1967;22:546-554. 
23. Clayton JM. Congenital dental anomalies occuring in 3557 children. ASDC J Dent Child 1956;23:206-208.

24. Niswander JD, Sujaku C. Congenital Anomalies of Teeth in Japanese Children. Am J Phys Anthropol 1963;21:569-574.

25. Brook AH. A unifying aetiological explanation for anomalies of human tooth number and size. Arch Oral Biol 1984;29:373-378.

26. Hagman FT. Anomalies of form and number, fused primary teeth, a correlation of the dentitions. ASDC J Dent Child 1988;55:359-361.

27. Jarvinen S, Lehtinen L, Milen A. Epidemiologic study of joined primary teeth in Finnish children. Community Dent Oral Epidemiol 1980;8:201-202.

28. Jarvinen S. Supernumerary and congenitally missing permanent upper anterior teeth in 7-year-old Finnish children A radiographic study. Proc Finn Dent Soc 1976;72:99-102.

29. McKibben DR, Brearley LJ. Radiographic determination of the prevalence of selected dental anomalies in children. ASDC J Dent Child 1971;28:390-398.

30. Brook AH, Winter GB. Double teeth. A retrospective study of 'geminated' and 'fused' teeth in children. Br Dent $J$ 1970;129:123-130.

31. Guttal KS, Naikmasurb VB, Bhargavac P, Bathid RJ. Frequency of developmental dental anomalies in the Indian population. Eur J Dent 2010;4:263-269.

32. Gellin ME. The distribution of anomalies of primary anterior teeth and their effect on the permanent successors. Dent Clin North Am 1984;28:69-80.

33. Jarvinen S, Lehtinen L. Supernumerary and congenitally missing primary teeth in Finnish children. An epidemiologic study. Acta Odontol Scand 1981;39:83-86.

34. Luten JR Jr. The prevalence of supernumerary teeth in primary and mixed dentitions. J Dent Child 1967;34:346-353.

35. Saarenmaa L. The origin of supernumerary teeth. Acta Odontol Scand 1950;9:293-303.

36. Oehlers F. Unilateral duplication of the maxillary decidious canine Br Dent J 1950;88:188.

37. Stevenson W. Supernumerary Canines; Report of an Unusual Case. Br Dent J 1965;118:257-258.

38. Pindborg J. Pathology of the dental hard tissues. Copenhagen; Munksgaard, 1970;28. 